https://doi.org/10.48009/1_iis_2008_21-29

\title{
A STUDY OF ICT ISSUES IN HIGHER EDUCATION AT TAIWAN, R.O.C. AND TEXAS, U.S.A.
}

\author{
Li-Jen Y. Shannon, Sam Houston State University, lys001@shsu.edu \\ Peter A. Cooper, Sam Houston State University, cooper@shsu.edu
}

\begin{abstract}
In this paper, we share the results of a study which analyzed the preparedness of the Millenial Generation (MG) of university students for a technology-driven world in both Taiwan, R.O.C. and Texas, U.S.A. in Spring 2006. To measure technological preparedness, we examined the MG's information and computer technology (ICT) literacy levels as well as their comfort levels with digital life environments (DLE). This comparative quantitative study analyzed data from students' self-report questionnaires from one state university in Texas and one national university in Taiwan. A total of 910 students were analyzed. Findings indicate there is a positive correlation between the students' ICT literacy levels with: (a) working hours on computers to complete coursework, and (b) comfort levels with DLE. Our study attempted to understand better how to address the needs of the MG students by analyzing both their perceptions of their ICT literacy levels and their comfort levels with DLE. The results of our study provide valuable information regarding how to best design the curriculum and instruction in higher education in order to prepare the MG for a technology-driven world.
\end{abstract}

Keywords: Curriculum Development, Higher Education, Information and Communication Technology (ICT), Millennial Generation,

Multimedia

\section{INTRODUCTION}

In the past 25 years, college enrollment in the U.S.A. have grown from 8.6 million to 16.5 million students, and it is predicted that enrollment in college will reach as high as 18.2 million by 2013 [25]. According to the U.S. Census Bureau's report School Enrollment-Social and Economic Characteristics of Students, October 2003, the number of students under 25 in the U.S.A. will increase markedly over the next decade as well [26]. With freshman enrollment in higher education steadily increasing, the Millennial Generation (MG) has become the majority population on campus [9]. The term, Millennial Generation (MG), was coined alongside Generation Y, the Net
Generation, and the MTV Generation in 1993 and represents the generation born after 1982 [13].

In order to reach USA national education goals (No Child Left Behind Act), university governing boards, such as the Texas Higher Education Coordination Board (THECB), have initiated projects such as Closing the Gaps by 2015 to define the future direction of higher education [21]. THECB's Closing the Gaps project is intended to: (a) increase participation in higher education and success rates as measured by graduation for all students; (b) increase educational excellence; and (c) guide funded research over the next 15 years. The International Society for Technology in Education (ISTE) and the National Educational Technology Standards (NETS) have similar goals toward which they provide resources to improve educational environments by advancing the effective use of technology for all students [10]. In addition, studies support the notion that the quality of information and communication technology (ICT) literacy skills are as important as competencies in mathematic, writing, and reading in higher education [27].

The $79^{\text {th }}$ Texas legislature is limiting the number of hours undergraduate students can be required to take for a degree (120 semester hours). Through legislation, they are addressing the "Time-ToDegree” issue by offering “...incentives to encourage institutions to structure offerings in ways that students can take the classes they need...." [21]. Because of this reduction in the number of required courses, concerns have been raised regarding what classes are vital for students to take and what are not. In some universities, computer or technology literacy courses have been a prime target for removal from required or core courses.

\section{USA Studies}

Even though the MG is familiar with surfing the web, chatting by instant messages, sharing web logs, and playing computer games, this group may not be developing the technological skills necessary for educational, vocational, and civic success in the $21^{\text {st }}$ century [11]. In 1999, Georgetown College established the Information Technology Literacy 
Program which included entry level assessments [18]. Test results from these assessments were used as an advising tool to determine whether each student needed to take an introductory computer course to meet the proficiencies in the use of informationtechnology resources. A list of schools from 16 states in the U.S.A. participated in this technology assessment project including: Alabama, Florida, Georgia, Illinois, Indiana, Iowa, Kentucky, Maine, Michigan, Minnesota, Missouri, New York, North Carolina, Pennsylvania, South Carolina, and Tennessee (2001). The results of this testing program indicated that the pass rate in initial information and technology was less than 50\% (2001). This suggests that there were a significant number of incoming students not technology proficient in 2001.

In 2005, Hardy conducted a study of Midwest students' technology skills. Findings from this study also indicated that the majority of students did not demonstrate mastery or proficiency on the overall computer/literacy skills assessment [7]. This study demonstrated a need for computer concepts to be taught at the post-secondary level. Results from the Midwest study also indicated that there was no significant difference in students' knowledge of computer concepts with respect to their home state, number of high school courses taken, gender, or major field of study.

\section{Asian Studies}

To compare the technology usage in the USA with that of Asian countries, we selected Japan and the East Asian Tigers (Hong Kong, Singapore, South Korea, and Taiwan) to represent the Asian countries. These countries and territories are noted for maintaining high growth rates and rapid industrialization comparing with the rest of Asia [1]. The CIA (2008) reported the percentages for both internet users and mobile cellular users in Taiwan, Hong Kong, Japan, Singapore, South Korea, and the USA as shown in Table 1 [22].

Table 1. Percent of Communication Devices Used in Asian Countries and USA, 2003

\begin{tabular}{lcc} 
Country & $\begin{array}{c}\text { Internet User } \\
\text { Percentages }\end{array}$ & $\begin{array}{c}\text { Mobile/cellular } \\
\text { Phone Use } \\
\text { Percentages }\end{array}$ \\
\hline Japan & 44.89 & 68.01 \\
Hong Kong & 46.57 & 104.97 \\
Singapore & 52.19 & 79.58 \\
South Korea & 11.12 & 74.90 \\
Taiwan & 60.28 & 109.59 \\
USA & 53.76 & 53.67
\end{tabular}

Interestingly enough, even with Taiwan's high computer usage, Taiwanese universities still require the introductory computer course as a core course for the non-engineering/technology programs [15]. The question "Why are basic computer courses in the U.S.A. being cut from degree programs when in Taiwan they are being required?” lead us to further investigate the needs and expectations of students in both universities.

\section{PURPOSE OF THE STUDY}

The purpose of this study was to study the Millennial Generation's (a) ICT literacy levels, and (b) comfort levels in digital life environment (DLE) as before they take the introductory computer course from both selected universities in Texas and Taiwan.

The majority of the general population perceives the Millenial Generation student as being technologically competent. Not only does public opinion appear to indicate such, but, according to Sanchez (2003), the MG overstated its own computer skills. It appears that, this generation also encounters difficulty in other academic areas due to the gap between reality and assumptions of high computer competency from instructors [3, 19]. Ethnicity appears to be a factor in terms of computer literacy skills and usage. Based on the ethnicity data from the U.S. Census Bureau report (2003), Presence of a Computer and the Internet for Households, October 2003, there is a significant gap in the use of technology between different ethnic groups. Non-Hispanic White and Asian populations in the U.S. experience the highest rate of technology use, with African American and Hispanic populations experiencing lower rates[26].

\section{RESEARCH QUESTIONS}

The research questions guiding this study were:

1. To what degree is there a correlation between the Millennial Generation's demographic information and computer technology literacy levels before an introductory computer course was taken?

2. To what degree is there a correlation between the Millennial Generation's demographic information and their comfort levels with DLE before an introductory computer course was taken?

3. To what degree is there a correlation between the Millennial Generation's information and computer technology literacy levels and their comfort levels with DLE? 


\section{RESEARCH METHODOLOGY}

We distributed a self-report questionnaire to the students who are members of the MG and who were enrolled in an introductory computer course from both selected universities in Taiwan and Texas. The Statistical Package for the Social Sciences (SPSS) version 15.0 was utilized to analyze the independent and dependent variances.

To discover differences, relationships, and effects between the two universities, the statistical power analysis was utilized for studying the likelihood of MG's ICT literacy levels and comfort levels with DLE between these two universities. Cohen (1988) stated that the larger the sample size, the smaller the error and the greater the reliability or precision of the results [4]. The total usable sample for this study was 910 which strengthened the reliability of our results. However, the results of our study cannot be generalized to the entire population of Texas, the U.S., or Taiwan; rather, the results are limited to universities similar in context, including population, size, wealth and enrollment.

\section{Population of the Study}

The members of the MG are considered to be those born after 1980 [9, 14, 19]. Since multimedia technologies have become a main part of the MG's daily lives, this young generation is becoming a multimedia-dependent society $[16,17]$.

To study the MG university students' computer use and skills, we selected one state university in Texas and one national university in Taiwan and analyzed both their information and computer technology (ICT) literacy levels and their comfort levels with digital life environment (DLE). The universities in Texas and Taiwan were selected for their population, size, and suburban-rural setting. These two selected universities are both situated in the southeastern rural area of their country. The university funding system for both universities is based on governmental budgets and research funds. The universities' missions are also similar for engaging the students in the work of life itself and instilling in the students professional expertise, humanistic concerns, and scientific competence. These two universities offer the academic programs of art and science, business administration, education, and humanities and social sciences. Master and doctoral programs are offered at both universities.

The total student enrollment in the spring semester, 2006 was approximately 5,600 from the selected university in Taiwan and 15,300 from the selected university in Texas. Students enrolled in basic (introductory) level computer literacy courses at each of these universities and colleges participated in the study shown that there were approximately 350 students enrolled in an introductory computer course from the selected university in Taiwan and 1,100 students enrolled in an introductory computer course from the selected university in Texas. We collected 339 forms and analyzed 324 valid surveys which were 92.6 percent of the purposeful sample from Taiwan. For the Texas population, we collected 628 forms and analyzed 586 valid surveys which were 53.3 percent of the purposeful sample from Texas. By selecting this purposeful sample, we were able to analyze the MG students' demographic information, their prior experiences with computers, the MG's ICT literacy levels of knowledge in specific skill areas, and their comfort levels with the DLE by subcategories.

\section{Instrumentation}

A self-report questionnaire addressed the following three areas; (a) the MG's demographic information and prior experiences with computers, (b) the MG's comfort levels with the DLE by sub-categories, and (c) the MG's ICT literacy levels of knowledge in specific skill areas.

Since Chinese is one of our authors' native languages. We did not need to depend on a translator to convert this research questionnaire from English to Chinese. We used a traditional form of Chinese for the language of the survey used in Taiwan. To prevent the language bias and misuse of technological terms, the faculties of the Division of Student Life Services from the selected university in Taiwan authenticated this Chinese questionnaire version.

Regarding demographics and experiences with computers, the demographic information was included:

1. year of birth,

2. student classification,

3. college major,

4. gender, and

5. ethnicity

Questions regarding computer experience included:

1. experiences with multimedia classroom

2. environments,

3. communication methods preference,

4. hours working with computers for coursework,

5. grade point average in coursework, and

6. ownership of digital devices. 
To study the MG's comfort levels with the DLE by sub-categories, the questionnaire was constructed using a Likert scale of 1 to 5 using the following measures: "Strongly Disagree", "Minor Disagree", "Neutral" , "Minor Agree", and "Strongly Agree". The nine sub-categories in this section included questions related to the student's beliefs regarding:

1. how multimedia technologies enhance students' learning (Multimedia Technology),

2. how web enhancement programs improve students' learning experience (Webenhancement),

3. how web enhancement programs should be integrated into the course (Web-enhancement Integration),

4. the degree to which technology should be implemented in classes (Technology in the university),

5. how on campus technology impacts the students' life,

6. the degree to which required computer literacy courses are valuable,

7. the degree to which technology implementation at the university influences the decision to graduate (Graduating from the university),

8. their willingness to take online courses (Online Courses), and

9. their comfort level working with computer applications (Digital Life Environment).

To evaluate the MG's ICT literacy levels of knowledge in specific skill areas, the questionnaire was constructed using a Likert scale of 1 to 5 which measures the skill areas from "No Knowledge", "Basic", "Average", "Advanced", to the "Expert" level. Overall, there were 55 survey items included for the 13 specific skill areas. The 13 skill areas included:

1. computer hardware including hardware components, $C P U$ process, input and output devices, and memory [23, 24];

2. computer software including network, BIOS boot process, and operating concept [24];

3. file management including explorer, organization, desktop, and screen shots [18, 23, 24];

4. Microsoft Word including alignment, font, format, page setup, insert, WordArt, and web page [8, 18, 24];

5. Microsoft Excel including formula, chart, fill handle, function, merge cell, and organization [8, 18, 24];

6. Microsoft Access including database design, calculation, sort, link, query, report, and import data $[2,18,24]$;
7. Microsoft PowerPoint including design, bullet, border, table, slide master, import data, slide view, and animation [18, 23, 24];

8. Web design including Microsoft FrontPage, html, and link [2, 23, 24];

9. internet browsers including browsers, search engines, and save data [2, 23, 24];

10. email including attachments, global emails, and save emails [2, 18, 23];

11. $C D$ burners including data, and music file [24];

12. file transfer applications including FTP, and WinZip applications [2, 8, 23, 24]; and

13. multimedia editing software including web design, audio, movie, and graphic software $[2,8$, 23, 24].

\section{Reliability}

This study provided an analysis of the MG's ICT literacy levels and their comfort levels with their DLE before the MGs complete their introductory computer literacy course from the universities. Specifically, we were able to obtain comparative result between the two universities from Taiwan and Texas. "A self-report measure is a paper-and-pencil instrument whose items yield numerical scores from which inferences can be made about how individuals differ on various aspects of self [1]. To ensure the internal consistency of each category, the Cronbach's alpha test was utilized to determine the degree of coefficient level for each individual item [5].

For ICT literacy levels consisting of 13 constructs with two to seven sub-categories, the Cronbach's alpha measure varied from .568 to .980 which indicated that each category presented a statistically significant correlation within each construct.

The Millennial Generation's comfort levels in DLE consisted of nine categories. Of these nine categories, the $7^{\text {th }}$ and 8th category indicated a low inter-item correlation. Based on the inter-item correlation matrix results, these two categories had a value of below 0.139. Gall, Gall, \& Borg stated that correlations in the range of .20 to .40 might be all that one should expect to find for many of the relationships between variables. We eliminated these two categories to analyze the MG's comfort levels with DLE items. Furthermore, we also studied the Cronbach's alpha under two conditions. One included all nine DLE items and the other included seven items without the low inter-item correlation value. The results indicated that the comfort levels with DLE had a statistically significant correlation of .810 compared to the correlation of .836 after dropping the two DLE categories. Although the difference was 
minor in Cronbach's alpha between seven and nine DLE items, further analysis for comfort levels with DLE were evaluated with seven items to ensure the power of analysis.

\section{Validity}

In designing the instrument for this study, we relied on both our own knowledge and experience in technology and computer science and those of experts in the field. To enhance the validity of this study, the self-report questionnaire was reviewed and edited by colleagues and chair-persons in the Department of Computer Science as well as the Director of Educational Leadership and Counseling. The authors have over twenty years of experience in each of their fields. The computer science colleagues and the department chair of computer science worked closely to provide guidelines of teaching objectives for the introductory computer literacy courses. Merging the guidelines with the context of ICT from the literature reviews, the instrument content might be able to provide a deeper view from the individuals.

\section{Data Collection}

At the beginning of spring semester, 2006, the students voluntarily completed a hard copy form of instrument. After reviewing the human subject protection letter with the students, the faculty of the Computer Science Department from the university in Texas distributed and collected the questionnaires. The faculty of the Division of Student Life Services from the university in Taiwan distributed, collected, and mailed the questionnaires back to us.

\section{Data Analysis}

Normality tests were reviewed at the beginning of data analysis. We tested the variance of each variable to investigate the stableness at all levels of the variances. For interval data and independence assumption, the categories and specific skill areas were measured under more than one experimental condition. The critical value of $F$ ratio determined to identify the difference between the variances. By using multivariate analysis of variance (MANOVA), the statistically significant differences in between the independent and dependent variances were analyzed. To examine the reliability of MANOVA, we used analysis of variance (ANOVA) and independent $t$ test to confirm the findings.

We also compared the correlations between the variances at an alpha of 0.05 . To ensure internal consistency, we determined the effect size (ES) to the following standard which the ES can be measured as the correlation between the independent variable classification and the individual scores on the dependent variable [4]. To prevent future difficulties from occurring, the effect size measures for two independent groups and in analysis of dependent variances were analyzed as well.

\section{RESULTS}

Research Question 1. To what degree is there a correlation between the Millennial Generation's demographic information and their computer technology literacy levels before an introductory computer course was taken?

As Table 2 shown, we found there is a statistically significant positive correlation between the MG's ICT literacy levels with (a) the hours working on coursework with computers, and (b) the ownership of digital devices from the university in USA. In addition, we found a positive relationship between their literacy levels and their desire to use email to communicate with their instructors.

We also found there is a statistically significant positive correlation between the MG's ICT literacy levels with the hours working on coursework with computers from the university in Taiwan.

Table 2. Correlation between the MG's demographic information and their ICT literacy levels

\begin{tabular}{lccl} 
Demographic & $\mathbf{N}$ & $\begin{array}{c}\text { Pearson } \\
\text { Correlation }\end{array}$ & $\begin{array}{l}\text { Pearson } \\
\text { Sign. }\end{array}$ \\
\hline Working hours & 586 & .192 & $.000^{*}$ \\
Digital devices & 586 & .202 & $.000^{*}$ \\
Email & 586 & .070 & $.091 *$
\end{tabular}

Note. ${ }^{*} p<.05$

Using independent $t$ test, the results showed that in the university in Taiwan, the female MGs have a significant higher ICT literacy levels than the male MGs’ ICT literacy levels $(F=10.866, t<0.001)$.

We also compared the MGs' ICT literacy levels for both universities and found that MGs from the university in Texas evaluated themselves with a higher level than MGs from the university in Taiwan for all of the ICT items, excepted FTP item. Four applications showed a significant different in MGs' ICT literacy levels: Word, Excel, Access, and Multimedia applications.

Research Question 2. To what degree is there a correlation between the Millennial Generation's 
demographic information and their comfort levels with DLE before an introductory computer course was taken?

We found a very different pattern of correlations for these two countries as showed in Table 3. In the Texas university, there is a statistically significant positive correlation between the MGs' demographic information and their comfort levels with DLE in the following areas:

1. Ownership of digital devices as it relates to belief in the web-enhancement integration into the courses

2. Working hours on the coursework with computer as it relates to preference to graduating from the university that implemented more technology

3. Preference in sending emails to communicate with professors as it relates to willingness to take online courses

4. Preference in sending emails to communicate with professors as it relates to comfort levels working with digital life computer applications

Table 3. Correlation between the MG's demographic information and their comfort levels with digital life environment from the university in Texas

\begin{tabular}{|c|c|c|c|}
\hline $\begin{array}{l}\text { Demographic } \\
\text { Information and } \\
\text { Comfort levels }\end{array}$ & $\mathbf{N}$ & Pearson & $\begin{array}{c}\text { Pearson } \\
\text { Sign. }\end{array}$ \\
\hline $\begin{array}{l}\text { Digital Devices and } \\
\text { Web-enhancement }\end{array}$ & 586 & .080 & .052 \\
\hline $\begin{array}{l}\text { Working Hours and } \\
\text { Technology in the } \\
\text { University }\end{array}$ & 586 & .103 & $.013^{*}$ \\
\hline $\begin{array}{l}\text { Emails and Online } \\
\text { Courses }\end{array}$ & 586 & .113 & $.006^{*}$ \\
\hline Emails and Digital & 586 & .144 & $.000 *$ \\
\hline
\end{tabular}

In Taiwan, the selected university showed there is a statistically significant positive correlation between the following areas (see Table 4):

1. Ownership of digital devices as it relates to graduating from the university that implemented more technology

2. Ownership of digital devices as it relates to willingness to take online courses

3. Preference for using the phone to communicate with professors as it relates to online courses
Table 4. Correlation between the MG's demographic information and their comfort levels with digital life environment from the university in Taiwan

\begin{tabular}{lccc}
$\begin{array}{l}\text { Demographic and } \\
\text { Comfort Level }\end{array}$ & N & Pearson & $\begin{array}{c}\text { Pearson } \\
\text { Sign. }\end{array}$ \\
\hline $\begin{array}{l}\text { Digital devices and } \\
\text { College decision }\end{array}$ & 324 & .175 & $.002^{*}$ \\
$\begin{array}{l}\text { Digital devices and } \\
\text { Online courses }\end{array}$ & 324 & .186 & $.001^{*}$ \\
$\begin{array}{l}\text { Phone and Online } \\
\text { courses }\end{array}$ & 324 & .185 & $.001^{*}$ \\
& & &
\end{tabular}

We found a statistically significant different between (a) the MGs' birth year and the levels of believing that multi-media technology will enhance learning; and (b) the gender and their comfort levels working with digital life environments regarding computer applications. The results indicated that the older groups of MGs have a significant higher belief that multi-media technology will enhance learning $(f=3.962, t=0.020)$. We also found that the female groups have significantly higher comfort levels working with digital life computer applications than males $(f=7.828, t=0.008)$.

Research Question 3. To what degree is there a correlation between the Millennial Generation's information and computer technology literacy levels and their comfort levels with DLE?

Analyzing the data from both universities, we found there is a significant positive pattern between the MGs' ICT literacy levels and their comfort levels with DLE.

1. MGs believe multi-media technology will enhance learning.

2. MGs believe the use of web-enhancement programs improve their learning experience.

3. MGs expect technology to be implemented in the classes.

4. MGs believe technology campus support impacts their student life.

5. MGs feel that the web-enhancement program should be well-integrated into the courses.

6. MGs agree that the degree to which technology is implemented in a university influences their decision to graduate at the university.

7. MGs are willing to take online courses.

The correlations between the MGs' ICT literacy levels and their belief that the introductory computer course is valuable for their academic performance were different for the two university groups of MGs. The MGs in the university in Taiwan had a significant positive correlation $(p=0.141$, $r h o=0.195$, 
$t<0.001)$. The MGs in the university in Texas showed a negative correlation $(p=-0.009$, rho $=0.002, t>0.05)$, although the correlation is not statistically significant.

We found that the higher ICT literacy levels at which the MGs evaluated themselves, the higher comfort levels with DLE they have as shown in Table 5 and Table 6 below.

Table 5. Correlation between the MG's ICT literacy levels and their Comfort levels with DLE from the university in Texas

\begin{tabular}{lccc}
$\begin{array}{l}\text { Comfort Levels } \\
\text { with DLE }\end{array}$ & $\mathbf{N}$ & Pearson & $\begin{array}{c}\text { Pearson } \\
\text { Significant }\end{array}$ \\
\hline $\begin{array}{l}\text { Multi-media } \\
\text { technology }\end{array}$ & 586 & .211 & $.000^{*}$ \\
$\begin{array}{l}\text { Learning \& } \\
\begin{array}{l}\text { Web- } \\
\text { enhancement }\end{array}\end{array}$ & 586 & .186 & $.000^{*}$ \\
$\begin{array}{l}\text { Technology } \\
\text { implemented }\end{array}$ & 586 & .217 & $.000^{*}$ \\
$\begin{array}{l}\text { Technology } \\
\text { support }\end{array}$ & 586 & .146 & $.000^{*}$ \\
$\begin{array}{l}\text { Integrated Web- } \\
\text { enhancement } \\
\text { College }\end{array}$ & 586 & .176 & $.000^{*}$ \\
decision \& & 586 & .072 & .083 \\
$\begin{array}{l}\text { Technology } \\
\text { Online Courses }\end{array}$ & 586 & .162 & $.000^{*}$
\end{tabular}

Table 6. Correlation between the MG's ICT literacy levels and their comfort levels with DLE from the university in Taiwan

\begin{tabular}{lccc}
$\begin{array}{l}\text { Comfort Levels } \\
\text { with DLE }\end{array}$ & N & Pearson & $\begin{array}{c}\text { Pearson } \\
\text { Sign. }\end{array}$ \\
\hline $\begin{array}{l}\text { Multi-media } \\
\text { technology }\end{array}$ & 324 & .191 & $.001^{*}$ \\
$\begin{array}{l}\text { Learning \& Web- } \\
\text { enhancement }\end{array}$ & 324 & .203 & $.000^{*}$ \\
$\begin{array}{l}\text { Technology } \\
\text { implemented }\end{array}$ & 324 & .317 & $.000^{*}$ \\
$\begin{array}{l}\text { Technology support } \\
\begin{array}{l}\text { Integrated Web- } \\
\text { enhancement }\end{array}\end{array}$ & 324 & .141 & $.011^{*}$ \\
$\begin{array}{l}\text { College decision \& } \\
\text { Technology }\end{array}$ & 324 & .172 & $.002^{*}$ \\
$\begin{array}{l}\text { Online Courses } \\
\text { nntione }\end{array}$ & 324 & .242 & $.000^{*}$ \\
\end{tabular}

Comparing the MGs from both universities, we found that the MGs from the university in Taiwan have a significantly lower comfort levels with DLE than the MGs from the university in Texas for the following four areas:
1. Believing multi-media technology will enhance learning

2. Believing the use of web-enhancement program improve their learning experience

3. Believing technology supports impact their student life.

4. Believing that the web-enhancement program should be well-integrated into the courses.

We found that MGs from the university in Taiwan have a significant higher comfort levels with DLE than the MGs from the university in Texas in the following two areas:

1. Agreeing that technology implementing in university influences their decision to graduate at the university.

2. Feeling comfortable working with digital life computer applications.

\section{CONCLUSIONS}

The results shows a consistent and positive correlation among the MGs' ICT literacy levels, their comfort levels with DLE, and their comfort levels with DLE regardless of the cultural differences. The CIA (2008) report that the percentages for mobile cellular users in Taiwan was $109.59 \%$ and in the USA was $53.67 \%$ well supported the different technological perspectives in both countries. The MGs in Taiwan prefer to communicate with the instructors by phone and the MGs in Texas prefer to do so by sending emails. We also found that the MGs in Taiwan are more comfortable working with digital life computer applications; even though they evaluated their ICT literacy levels as lower than the MGs in Texas. Whether these groups overstate or understate their ICT literacy levels cannot be answered from this study; but the result do show a positive correlation between their ICT literacy levels and the degree to which they value the introductory computer course in Taiwan. This study shows an example of continuing education in ICT from the university in Taiwan. In order to maintain the status of high economics growth and rapid industrialization, the institution in Taiwan recognizes the need of a fundamental computer (technology) course for their students.

To live in the digital environment, there is an obvious need for computer literacy and technology skills and knowledge in schools, the workforce, and society. While studies have called for computer skills acquisition and development, some educational programs have a clearer and better-developed vision than others of what those skills are and how they may 
be introduced and cultivated. The growing emphasis on computer skills is an indication that what began as a fundamentally technology-oriented discipline is evolving into a technology-based profession [1].

Today, colleges and universities have made major investments in technology and are still exploring and creating ways of applying technology's potential to improve learning outcomes. More institutions will collaborate in the development of technology in order to increase the quality and affordability of services for students who expect easy access to all services all the time [12]. For example, whether the ICT literacy levels differ from the MG in Taiwan and in the USA should be investigated because an introductory computer course may be a vital tool for the institutions to closing the technological gaps between student groups.

To further study the impact of introductory computer courses, we suggest that an identical follow-up survey be given at the end of the introductory computer course to determine how helpful the courses are in promoting the success of the MGs student life. We also suggest that a future study may consider evaluating the students with a researchbased ICT test program to measure their ICT literacy levels for placement in courses and designing or modifying curriculum.

\section{REFERENCES}

1. Asian Tiger Group. (2008). Asian Tigher Group Home page. Retrieved March 3, 2008, from http://www.asiantigersgroup.com/frontpage.htm

2. Carbonara, D. (2005). Technology literacy applications in learning environments. Hershey: Idea Group.

3. Carlson, S. The net generation in the classroom. (2005, October 7). The Chronicle of Higher Education, pp. A34-37.

4. Cohen, J. (1988). Statistical power analysis for the behavioral sciences. (2nd ed.). Hillsdale: Lawrence Erlbaum Associates.

5. Cronbach, L. J., Gleser, G.C., Handa, H., \& Rajaratnam N. (1972). The dependability of behavioral measurements: Theory of generalizability for scores and profiles. New York: Wiley.

6. Gall, M. D., Gall, J. P., \& Borg, W. R. (2003). Educational research an introduction. (7th ed.). Boston: Pearson Education.

7. Hardy, C.A. (2005). A study of Midwest students' technology skills (Doctoral dissertation, University of Nebraska, 2005) Dissertation
Abstracts International, A 66/08, p. 2898. (UMI No. 3186856)

8. Hefzallah, I.M. (2004). The new educational technologies and learning: empowering teachers to teach and students to learn in the information age. (2nd ed.). Springfield: Charles C Thomas Publisher.

9. Howe, N., \& Strauss, W. (2003). Millennials go to college: Strategies for a new generation on campus. Annapolis Junction: American Association of Collegiate Registrars and Admissions Officers.

10. International Society for Technology in Education (2008). ISTE Home page. Retrieved March 3, 2008, from http://www.iste.org

11. Kelly, M.G., \& Haber, J. (2006). Resources for students assessment. Eugene: ISTE.

12. Komives, S.R., Woodard, D.B. Jr., \& Associates. (2003). Student services. San Francisco: JosseyBass.

13. Life Course Associates. (2006). Millennial rising: The next great generation. Retrieved March 3, 2008, from http://www.millennialsrising.com/

14. Lowery, J.W. (2001, Jul - Aug). The millennials come to campus. About Campus, p. 6-12.

15. Ministry of Education, MOE Home page. Retrieved March 3, 2008, from http://140.111.1.22/english/

16. Oblinger, D. (2003, Jul - Aug). Boomers, GenXers, \& Millennials: understanding the new students. EDUCAUSE, p. 34-47.

17. Picciano, A. G. (2006). Educational leadership and planning for technology. (4th ed.). New Jersey: Pearson Prentice Hall.

18. Rafaill, W.S., \& Peach, A.C. (2001). Are your students ready for college? Technology literacy at Georgetown College. Proceedings of the Annual Mid-South Instructional Technology Conference (6th, Murfreesboro, TN, April 8-10, 2001).

19. Sanchez, J. (2003). Misreading millennials. Reason, 35, 7, 20.

20. Taylor, M. L. (2008). Meeting generation NeXt: Today's postmodern college student. TAMU Home page. Retrieved March 3, 2008, from www.taylorprograms.org/images/Gen_NeXt_arti cle_HLC_05.pdf

21. Texas Higher Education Coordination Board. (2008). THECB Home page. Retrieved March 3, 2008, from http://www.thecb.state.tx.us/

22. The Central Intelligence Agency (2008). The World Factbook. CIA Home page. Retrieved March 3, 2008, from http://www.cia.gov/cia/publications/factbook /index.html. 
23. Thorsen, C. (2006). TechTactics technology for teachers (2nd ed.). Boston: Pearson Education.

24. Tomei, L.A. (2005). Taxonomy for the technology domain. Hershey: Information Science Publishing.

25. U.S. Government. (2005, July). Recruitment retention in higher education. Copy Editor, 19, 7.

26. U.S. Census Bureau. (2008). U.S. Census Bureau Home page. Retrieved March 3, 2008, from http://www.census.gov/population/www/socdem o/computer.html

27. Young, J. R. (2005). Educational testing service expands efforts to measure computer literacy. The Chronicle of Higher Education, 52, 6. 